Tetsuya Yamada $\cdot$ Seiji Hayasaka $\cdot$ Masayuki Matsumoto

Budu • Tenri Esa $\cdot$ Yoriko Hayasaka $\cdot$ Machi Endo

\title{
Heterozygous 17-bp deletion in the forkhead transcription factor gene, FOXL2, in a Japanese family with blepharophimosis-ptosis-epicanthus inversus syndrome
}

\begin{abstract}
We examined mutations in the forkhead transcription factor gene, FOXL2, in three members of a Japanese family with autosomal dominant blepharophimosis-ptosis-epicanthus inversus syndrome (BPES) and in 100 healthy controls. The FOXL2 was analyzed by direct genomic sequencing. A novel 17-bp deletion at nucleotides 1092-1108 in FOXL2 was found in the three affected patients. No mutation was found in any of the 100 healthy controls. The 17-bp deletion in FOXL2 may be involved in the pathogenesis of BPES in Japanese patients.
\end{abstract}

Key words Forkhead transcription factor gene - FOXL2 . Blepharophimosis-ptosis-epicanthus inversus syndrome . BPES - Japanese patients

\section{Introduction}

Blepharophimosis-ptosis-epicanthus inversus syndrome (BPES) is a combination of congenital anomalies of the eyelid characterized by reduction of the horizontal fissure length, congenital ptosis, and epicanthus inversus (Amano et al. 1995; Matsuoka et al. 1997; Oley et al. 1988; Stromme et al. 1996). The syndrome may occur either sporadically or in an autosomal dominant mode. Two types of the syndrome have been proposed: type I with infertility in affected females and type II transmitted by females and males (Zlotogora et al. 1983). Genetic and chromosomal studies have indicated that one of the BPES loci exists at the $3 q$ region (Amati et al. 1996; Messiaen et al. 1996; Toomes et al. 1998). Crisponi et al. (2001) cloned a forkhead transcription factor gene, FOXL2, from that region and reported on mutations in the gene in five families and two sporadic

T. Yamada $(\bowtie) \cdot$ S. Hayasaka $\cdot$ M. Matsumoto $\cdot$ Budu $\cdot$ T. Esa

Y. Hayasaka $\cdot$ M. Endo

Department of Ophthalmology, Toyama Medical and

Pharmaceutical University, 2630 Sugitani, Toyama 930-0194, Japan

Tel. +81-764-34-7363; Fax +81-764-36-0146

e-mail: md991012@st.toyama-mpu.ac.jp patients with BPES. They suspected that the mutated FOXL2 gene produced truncated proteins in type I families and larger proteins in type II families (Crisponi et al. 2001). De Baere et al. (2001) also reported on the other 17 mutations of the FOXL2 gene in BPES patients. They demonstrated a genotype-phenotype correlation in which truncated FOXL2 proteins caused type I BPES and extended proteins caused type II BPES. We examined $F O X L 2$ genotypes in three Japanese patients from a family with BPES.

\section{Patients and methods}

Case reports

The pedigree of the affected family is shown in Fig. 1. The proband's parents had a nonconsanguineous marriage. A girl (proband, patient III-7) was born after a full-term pregnancy. At the time of birth, her mother and father were 30 and 33 years old, respectively. Her birth weight was $2600 \mathrm{~g}$. The patient had had abnormal eyelids bilaterally since birth. Her developmental milestones were within normal ranges. At the age of 5 years, she was referred to our clinic. On examination, her corrected visual acuity was 0.1 in the right eye and 0.6 in the left eye. Her horizontal palpebral fissures were $15 \mathrm{~mm}$ in both eyes (normal, 20-26 mm), indicating blepharophimosis. Her palpebral widths were $1 \mathrm{~mm}$ in the right eye and $3 \mathrm{~mm}$ in the left eye (normal, 4-6mm), indicating ptosis. Her right pupil was occluded by the upper eyelid. Epicanthus inversus was seen bilaterally (Fig. 2a). Cornea, anterior chamber, iris, pupil, lens, vitreous, and fundus appeared normal bilaterally. Her height was $108 \mathrm{~cm}$ and her body weight was $16.8 \mathrm{~kg}$. No other physical abnormality was noted. Her psychomotor development appeared normal. The 38-year-old father, patient II-8, had had BPES since birth (Fig. 2b). No other mental or physical abnormality was noted. The 71-year-old paternal grandfather, patient I-3, had had BPES since birth. He had undergone eyelid surgeries several times during childhood. However, the 


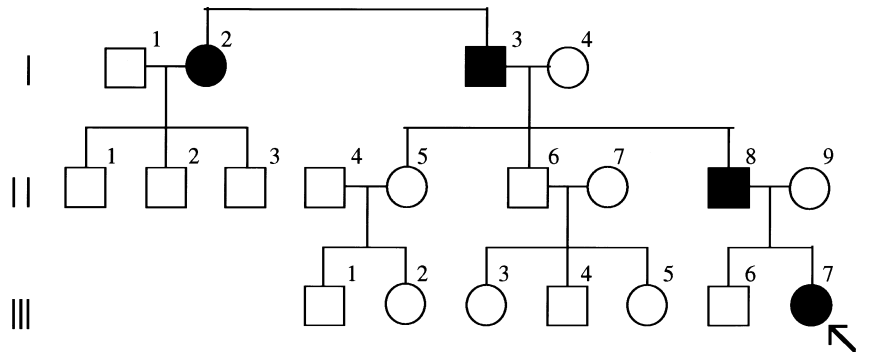

Fig. 1. Family tree. Open squares, normal man; Solid squares, affected man; Open circles, normal woman; Solid circles, affected woman; arrow, proband
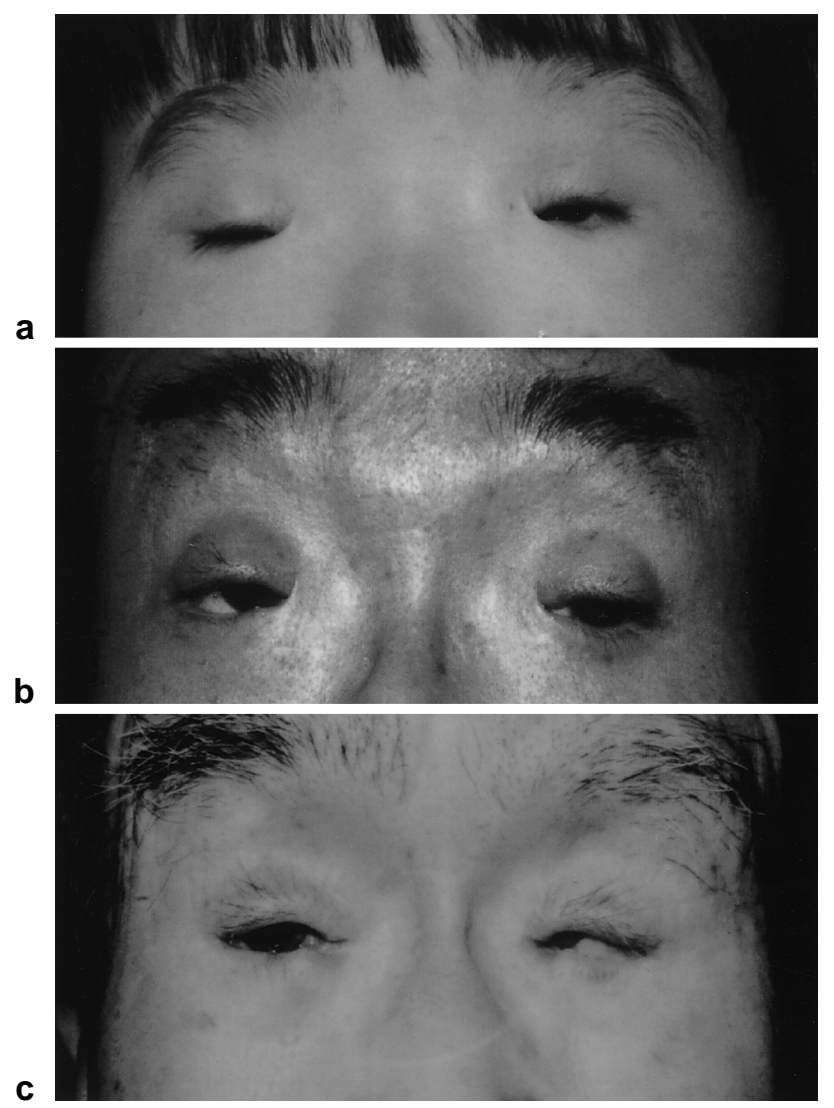

Fig. 2a-c. Eyelid photograph of a patient III-7 (proband), b patient II8 (proband's father), and c patient I-3 (proband's paternal grandfather). A bilateral reduction in horizontal fissure length, short palpebral width, and epicanthus inversus are seen in three patients

BPES remained (Fig. 2c). No other mental or physical abnormality was noted. The 74-year-old paternal grandaunt, patient I-2, was reported to have had BPES since birth. She had three sons. One hundred subjects with normal eyelids served as controls.

Informed consent was obtained from all individuals and/or their parents. Ten-millimeter samples of peripheral venous blood were collected from the three patients and healthy subjects. Genomic DNA was extracted from each sample. FOXL2 was amplified by polymerase chain reaction (PCR), according to a slight modification of the method described by Crisponi et al. (2001). In brief, four

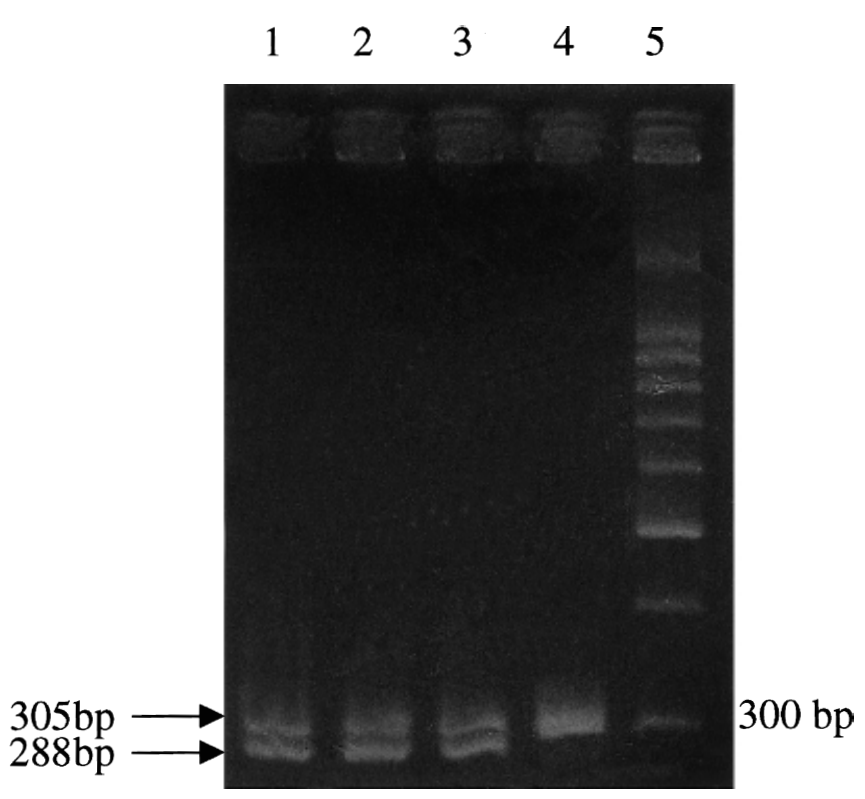

Fig. 3. Polyacrylamide gel electrophoresis. Lane 1, patient III-7 (proband); lane 2, patient II-8 (proband's father); lane 3, patient I-3 (proband's paternal grandfather); lane 4, normal control; lane 5, DNA markers. Two allele-fragments are found in lanes 1,2, and 3, and one fragment in lane 4

primer pairs were used according to the original method, and another primer pair (1, sense: 5'-TACACACGCGT GCAGAGCAT-3', and 2, antisense: 5'-AGAGCAATG CATCATGGCGA-3') was used. A total of $100 \mathrm{ng}$ DNA in $50 \mu \mathrm{l}$ of a solution containing $10 \mathrm{mM}$ Tris- $\mathrm{HCl}$ buffer $(\mathrm{pH}$ $8.0), 2.5 \mathrm{mM} \mathrm{MgCl}_{2}, 50 \mathrm{mM} \mathrm{KCl}, 0.2 \mathrm{mM}$ dNTPs, and $2.5 \mathrm{U}$ Taq polymerase were used for each reaction. After initial denaturation at $95^{\circ} \mathrm{C}$ for $5 \mathrm{~min}, 30$ cycles of PCR were performed. Each cycle consisted of denaturation at $95^{\circ} \mathrm{C}$ for $45 \mathrm{sec}$, primer annealing at $61^{\circ} \mathrm{C}$ or at $63^{\circ} \mathrm{C}$ for $45 \mathrm{sec}$, and extension at $71^{\circ} \mathrm{C}$ for $90 \mathrm{sec}$. All PCR products were sequenced with an automated DNA sequencer (ABI 310, Perkin Elmer Cetus, Fofter, CA, USA). For the agarose gel study, $5 \mu$ of PCR product (primer pairs 1 and 2), $1 \mu \mathrm{l}$ of loading dye $(40 \%[\mathrm{w} / \mathrm{v}]$ sucrose, $0.25 \%$ [w/v] bromophenol blue, and $1 \mathrm{mM}$ ethylenediaminetetraacetic acid) were combined, and were run on $3.5 \%$ agarose gels in $0.5 \times$ Tris[hydroxymethyl]aminomethane borate etylenediaminetetraacetic acid (TBE) at $100 \mathrm{~V}$ for $120 \mathrm{~min}$. The agarose gels were then stained for $15 \mathrm{~min}$ at room temperature with a $1 \mu \mathrm{l} / \mathrm{ml}$ ethidium bromide, $0.5 \times \mathrm{TBE}$ solution. Bands were visualized on an ultraviolet-transilluminator and photodocumented.

\section{Results}

Agarose gel electrophoresis showed two allele-fragments in patients III-7, II-8, and I-3, but one fragment in healthy controls (Fig. 3), suggesting heterozygosity in this region in the three affected patients. Sequence analysis revealed heterozygous 17-bp deletion at nucleotides 1092-1108 in FOXL2 in three affected patients of the family with BPES 
Fig. 4a,b. The sequence analysis around nt 1100 of FOXL2. a, normal control; b, patient III-7. Heterozygous 17-bp deletion at nt $1092-1108$ is seen in patient III-7

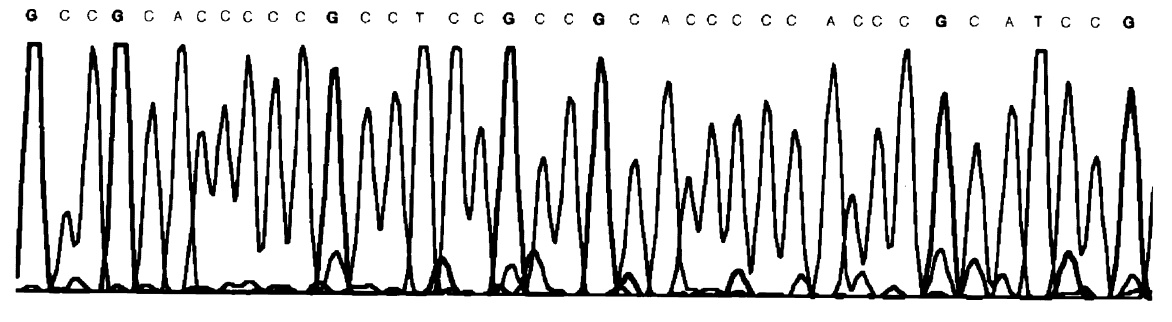

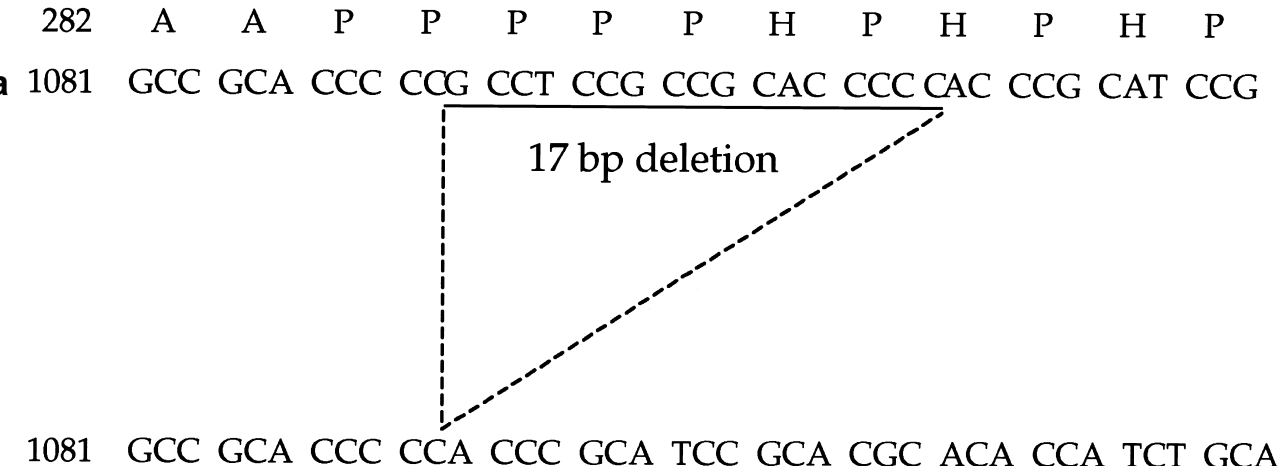




\section{References}

Amano T, Shibuya Y, Hayasaka S (1995) Blepharophimosis, ptosis, epicanthus inversus, telecanthus, amblyopia, and menstrual abnormality in sisters. Jpn J Ophthalmol 39:172-176

Amati P, Gasparini P, Zlotogora J, Zelante L, Chomel JC, Kitzis A, Kaplan J, Bonneau D (1996) A gene for premature ovarian failure associated with eyelid malformation maps to chromosome 3q22-q23. Am J Hum Genet 58:1089-1092

Conlon RM, Sutula FC (1994) Congenital eyelid anomalies. In: Albert DM, Jakobiec FA (eds) Principles and practice of ophthalmology. WB Saunders, Philadelphia, pp 1693-1702

Crisponi L, Deiana M, Loi A, Chiappe F, Uda M, Amati P, Bisceglia L, Zelante L, Nagaraja R, Porcu S, Ristaldi MS, Marzella R, Rocchi M, Nicolino M, Lienhardt-Roussie A, Nivelon A, Verloes A, Schlessinger D, Gasparini P, Bonneau D, Cao A, Pilia G (2001) The putative forkhead transcription factor FOXL2 is mutated in blepharophimosis/ptosis/epicanthus inversus syndrome. Nat Genet 27:159-166

de Baere E, Dixon MJ, Small KW, Jabs EW, Leroy BP, Devriendt K, Gillerot Y, Mortier G, Meire F, Van Maldergem L, Courtens W, Hjalgrim H, Huang S, Liebaers I, Van Regemorter N, Touraine P, Praphanphoj V, Verlose A, Udar N, Yellore V, Chalukya M, Yelchits S, De Paepe A, Kuttenn F, Fellous M, Veitia R, Messiaen L (2001) Spectrum of FOXL2 gene mutations in blepharophimosis- ptosis-epicanthus inversus (BPES) families demonstrates a genotype-phenotype correlation. Hum Mol Genet 10:1591-1600

Findlater GS, McDougall RD, Kaufman MH (1993) Eyelid development, fusion and subsequent reopening in the mouse. $\mathrm{J}$ Anat 183:121-129

Kaufmann E, Knochel W (1996) Five years on the wings of fork head. Mech Dev 57:3-20

Matsuoka Y, Shibuya Y (1997) Endometrial carcinoma in a patient with blepharophimosis syndrome and mental abnormality. Am J Ophthalmol 124:855-856

Messiaen L, Leroy BP, de Bie S, Pauw KD, van Roy N, Speleman F, van Camp G, de Paepe A (1996) Refined genetic and physical mapping of BPES type II. Eur J Hum Genet 4:34-38

Oley C, Baraister M (1988) Blepharophimosis, ptosis, epicanthus inversus syndrome (BPES syndrome). J Med Genet 25:47-51

Pearson AA (1980) The development of the eyelids. Part I. External features. J Anat 130:33-42

Stromme P, Sandboe F (1996) Blepharophimosis-ptosis-epicanthus inversus syndrome (BPES). Acta Ophthalmol Scand 74:45-47

Toomes C, Dixson MJ (1998) Refinement of a translocation breakpoint associated with blepharophimosis-ptosis-epicanthus inversus syndrome to a $280-\mathrm{kb}$ interval at chromosome $3 \mathrm{q} 23$. Genomics 53:308-314

Zlotogora J, Sagi M, Cohen T (1993) The blepharophimosis, ptosis, and epicanthus inversus syndrome: delineation of two types. Am J Hum Genet 35:1020-1027 